OPEN ACCESS

Edited by:

Hansen Wang,

University of Toronto, Canada

Reviewed by: Karen K. Szumlinski,

University of California,

Santa Barbara, United States

Mary M. Torregrossa,

University of Pittsburgh

United States

*Correspondence:

ZhenZhen Hu

huzhenzhen@ncu.edu.cn;

hzz99092@aliyun.com

tThese authors have contributed equally to this work.

Received: 20 April 2017 Accepted: 02 August 2017 Published: 15 August 2017

Citation:

Yu C, Zhou X, Fu Q, Peng Q, Oh K-W and $\mathrm{Hu} Z$ (2017) A New Insight into the Role of CART in Cocaine Reward: Involvement of CaMKII and Inhibitory

G-Protein Coupled Receptor

Signaling.

Front. Cell. Neurosci. 11:244. doi: 10.3389/fncel.2017.00244

\section{A New Insight into the Role of CART in Cocaine Reward: Involvement of CaMKII and Inhibitory G-Protein Coupled Receptor Signaling}

\author{
ChengPeng $\mathrm{Yu}^{1 \dagger}$, XiaoYan Zhou ${ }^{2 \dagger}$, Qiang Fu ${ }^{3,4}$, QingHua Peng ${ }^{5}$, Ki-Wan $\mathrm{Oh}^{6}$ \\ and ZhenZhen $\mathrm{Hu}^{2,7 *}$ \\ ${ }^{1}$ The Second Clinic Medical College, School of Medicine, Nanchang University, Nanchang, China, ${ }^{2}$ Department of \\ Pathophysiology, College of Medicine, Nanchang University, Nanchang, China, ${ }^{3}$ Department of Respiration, The Fourth \\ Affiliated Hospital, Nanchang University, Nanchang, China, ${ }^{4}$ Department of Respiration, Department Two, Jiangxi Provincial \\ People's Hospital, Nanchang, China, ${ }^{5}$ Department of Anesthesiology, The First Affiliated Hospital, Nanchang University, \\ Nanchang, China, ${ }^{6}$ College of Pharmacy, Chungbuk National University, Cheongju, South Korea, ${ }^{7}$ Jiangxi Province Key \\ Laboratory of Tumor Pathogens and Molecular Pathology and Department of Pathology, Schools of Basic Medical Sciences \\ and Pharmaceutical Sciences, Nanchang University Medical College, Nanchang, China
}

Cocaine- and amphetamine-regulated transcript (CART) peptides are neuropeptides that are expressed in brain regions associated with reward, such as the nucleus accumbens (NAc), and play a role in cocaine reward. Injection of CART into the NAc can inhibit the behavioral effects of cocaine, and injecting CART into the ventral tegmental area (VTA) reduces cocaine-seeking behavior. However, the exact mechanism of these effects is not clear. Recent research has demonstrated that $\mathrm{Ca}^{2+}$ /calmodulin-dependent protein kinase II (CaMKII) and inhibitory G-protein coupled receptor (GPCR) signaling are involved in the mechanism of the effect of CART on cocaine reward. Hence, we review the role of CaMKII and inhibitory GPCR signaling in the effect of CART on cocaine reward and provide a new insight into the mechanism of that effect. In this article, we will first review the biological function of CART and discuss the role of CART in cocaine reward. Then, we will focus on the role of CaMKII and inhibitory GPCR signaling in cocaine reward. Furthermore, we will discuss how CaMKII and inhibitory GPCR signaling are involved in the mechanistic action of CART in cocaine reward. Finally, we will provide our opinions regarding the future directions of research on the role of CaMKII and inhibitory GPCR signaling in the effect of CART on cocaine reward.

Keywords: CART, cocaine addiction, CaMKII, GABA $R$, $D_{3} R$

\section{INTRODUCTION}

Cocaine is a strong psychostimulant drug that can inhibit the reuptake of serotonin, norepinephrine and dopamine (DA). This results in greater concentrations of these three neurotransmitters in the brain. The drug can easily cross the blood-brain barrier and cause the user to feel intense euphoria (Pomara et al., 2012). In 2014, 18.3 million people were using cocaine worldwide. Cocaine can be administered by smoking, intravenous injection or inhalation, all of which can produce intense euphoric effects (United Nations Office on Drug and Crime (UNODC), 2016). Unfortunately, this euphoria can lead to increased frequency of use and dosage to obtain the same effect and to avoid the uncomfortable physiological and psychological effects linked to the cessation of drug use 
TABLE 1 | The evidence that cocaine- and amphetamine-regulated transcript (CART) plays an important role in cocaine reward.

\begin{tabular}{|c|c|c|c|c|}
\hline Species & Methods & Results & Mechanisms & References \\
\hline Rat & Cocaine administration & $\begin{array}{l}\text { CART expression } \uparrow \text { in brain } \\
\text { regions associated with reward }\end{array}$ & CAMP/PKA/CREB & $\begin{array}{l}\text { Lakatos et al. (2002) and } \\
\text { Cho et al. (2017) }\end{array}$ \\
\hline Rat & Intra-NAc CART & Locomotor activity $\downarrow$ & Inhibits the influx of $\mathrm{Ca}^{2+}$ & $\begin{array}{l}\text { Jaworski et al. (2003) and } \\
\text { Peng et al. (2014) }\end{array}$ \\
\hline Rat & Intra-NAc CART & Self-administration $\downarrow$ & $\mathrm{Ca}^{2+} / \mathrm{CaMKII}, \mathrm{D} 3 \mathrm{R}$ & $\begin{array}{l}\text { Jaworski et al. (2003) and } \\
\text { Jaworski et al. (2008) }\end{array}$ \\
\hline Rat & $\begin{array}{l}\text { Intra-paraventricular } \\
\text { thalamus CART }\end{array}$ & Cocaine-seeking behavior $\downarrow$ & Unclear & James et al. (2010) \\
\hline Human & Genetic studies & $\begin{array}{l}\text { Contributed to the etiology of } \\
\text { cocaine dependence }\end{array}$ & Unclear & Lohoff et al. (2008) \\
\hline
\end{tabular}

(Hou et al., 2014). Long-term and repeated cocaine use harms human health and contributes to crime, which places a great burden on families and society. However, the problem of cocaine abuse continues to spread. Therefore, there is an urgent need for new treatments to control and reduce the harm of cocaine abuse.

Cocaine- and amphetamine-regulated transcript (CART) is a neuropeptide that is expressed in brain regions associated with reward, such as the nucleus accumbens (NAc). During the last two decades, increasing evidence has demonstrated that CART plays a role in cocaine reward (Table 1). First, high densities of CART-containing nerve terminals are localized in brain regions associated with reward (Fagergren and Hurd, 2007). Second, injection of CART into the NAc can attenuate the behavioral effects of DA and cocaine (Hubert et al., 2008). Third, injection of CART into the paraventricular thalamus (PVT) can suppress cocaine-seeking behavior in rats (James et al., 2010). However, the mechanism by which CART inhibits the behavioral effect of DA is still not clear. Recently, some research has shown that $\mathrm{Ca}^{2+} /$ calmodulin-dependent protein kinase II (CaMKII) and inhibitory G-protein coupled receptor (GPCR) signaling are involved in the mechanism of the effect of CART on cocaine reward, which may explain how CART inhibits the behavioral effect of DA and may help establish a more comprehensive mechanistic model of the effect of CART on cocaine reward. In the following sections, we will first review the role of CART in cocaine reward and note the shortcomings of the currently proposed mechanism for the effect of CART on cocaine reward. Then, we will focus on the role of CaMKII and inhibitory GPCR signaling in cocaine reward. In addition, we will discuss how CaMKII and inhibitory GPCR signaling are involved in the mechanism of the effect of CART on cocaine reward. Finally, we will provide our opinions regarding the future directions of research on the role of CaMKII and inhibitory GPCR signaling in the effect of CART on cocaine reward.

\section{ROLES OF CART IN COCAINE REWARD}

\section{The Biological Features of CART}

Douglass et al. (1995) used differential display PCR to screen for specific mRNAs that are transcriptionally regulated by cocaine and amphetamine in specific brain regions in rats. The authors identified a previously uncharacterized mRNA that was extracted from the hypothalamus by Spiess et al. (1981) and named it CART (Zhang et al., 2012). In addition to the brain, CART is also expressed in the pituitary gland, adrenal medulla and pancreas in humans. The CART peptide contains 116 amino acids encoded by the cart gene, which is located on the 5th chromosome in humans (Robson et al., 2002). The cart gene is approximately $2 \mathrm{kbp}$ in length and contains two introns and three exons. There is a cyclic adenosine monophosphate (cAMP) response element (CRE) in the start codon of the cart gene (Perry Barrett et al., 2002). Therefore, CART could be upregulated by cocaine through the cAMP/protein kinase A (PKA)/CRE binding protein (CREB) signaling pathway. In addition to humans, the CART peptide has been found in other species, such as goldfish and mouse (Volkoff and Peter, 2001; Zhang et al., 2012). However, compared with humans, there are two alternatively spliced variants within exon 2 of rlCART. In goldfish, there are also two CART peptides. These two CART peptides originate not from alternative splicing but from the expression of two CART genes (Volkoff and Peter, 2001). Meanwhile, the sequence of the rat CART gene shows great homology with the human gene (Zhang et al., 2012). Many studies have demonstrated that the CART peptide can attenuate the behavioral effects of DA and cocaine and plays an important role in reward and reinforcement. In addition, the CART peptide is involved in feeding, stress and the regulation of the endocrine system (Asakawa et al., 2001; Kong et al., 2003; Larsen et al., 2003; Kuriyama et al., 2004; Koylu et al., 2006).

\section{CART Abnormalities in Cocaine Administration}

CART mRNA has been found to be upregulated by cocaine or amphetamine in the rat striatum (Volkoff and Peter, 2001). However, this result has not been consistently replicated (Vrang et al., 2002). Hunter et al. (2005) have demonstrated that chronic and acute administration of cocaine failed to upregulate the levels of CART mRNA or peptide, but binge administration of cocaine resulted in increased CART mRNA in the NAc. The involvement of corticosterone may account for the abovementioned inconsistent results (Hunter et al., 2005). Binge administration of cocaine could cause significant stress to 
the rats, and corticosteroids are involved in stress. Meanwhile, Hunter et al. (2005) found that corticosterone administration produced a significant increase in CART mRNA, which suggests that CART mRNA may be regulated by cocaine under certain conditions, such as binge administration, and this may at least partly involve corticosterone. As estradiol may interact with the DA system, there is also a sex difference in the effect of cocaine on CART. Fagergren and Hurd (1999) found that CART levels were elevated in the medial accumbens shell and the central amygdala of male but not female rats after the administration of cocaine (Rodrigues et al., 2011). Additionally, this research showed that CART mRNA expression did not exhibit marked alterations in specific regions of the rat brain during the early phase of cocaine self-administration (Rodrigues et al., 2011). Furthermore, CART expression levels were increased in the NAc of human cocaine abusers (Albertson et al., 2004; Bannon et al., 2005).

\section{The Effect of CART on Cocaine Reward}

Injection of CART peptide into the accumbens had no effect on locomotion (Kuhar et al., 2005). However, intra-accumbal CART attenuated the locomotor activity (LMA) produced by systemic cocaine and amphetamine administration. As cocaine induces LMA by potentiating dopaminergic transmission, the effect of CART 55-102 on DA-induced LMA was examined to explain the abovementioned phenomenon. As expected, CART peptide dose-dependently attenuated locomotion produced by intra-accumbal infusions of DA. These studies suggested that CART attenuates cocaine-induced LMA by attenuating the behavioral effect of DA. Meanwhile, intra-ventral tegmental

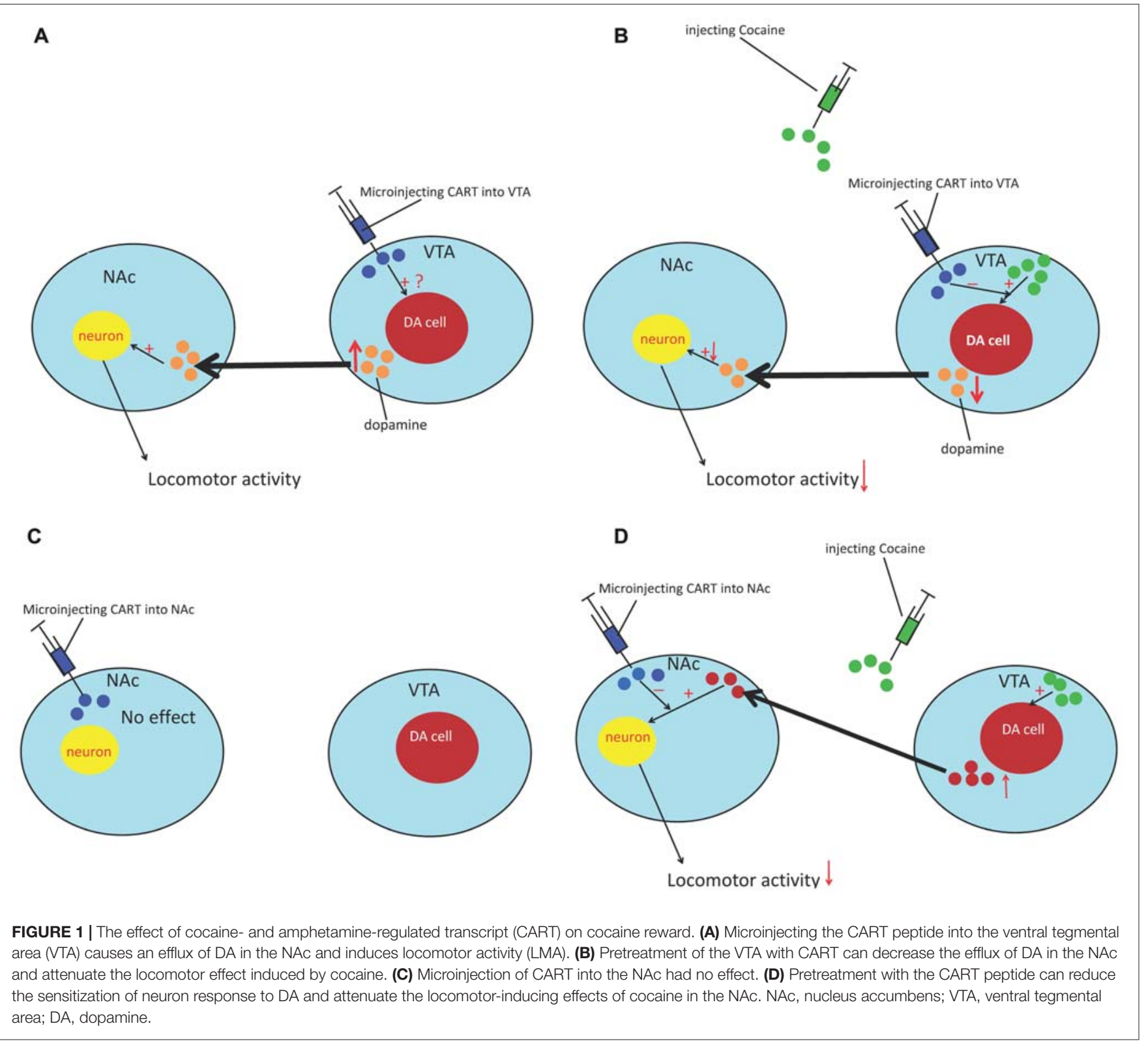


area (VTA) injection of CART induced LMA and promoted conditioned place preference. The effect on LMA was dose dependent and was blunted by a DA receptor antagonist (Kimmel et al., 2000) However, pretreatment of the VTA with CART attenuated the locomotor effect induced by cocaine administration (Jaworski et al., 2007). Regarding the different results in the NAc and VTA, the potential mechanism may involve the cell bodies of the mesolimbic system that are located in the VTA; CART can produce weak psychostimulant-like effects and causes an efflux of DA in the NAc, which produces weak LMA (Kuhar et al., 2005) and suggests that CART can activate the DA system, but not in the same manner as cocaine (Figure 1). Meanwhile, this inhibitory effect of CART peptide also generalizes to other measures of dopaminergic function such as reward/reinforcement. Jaworski et al. (2008) found that injecting CART into the NAc could reduce cocaine self-administration in rats. Furthermore, James et al. (2010) reported that injection of CART into the PVT could suppress cocaine-seeking behavior in rats (James et al., 2010). However, the mechanisms through which CART influences the DA system are still unclear. Therefore, in the following sections, we provide a putative mechanism that involves CaMKII and inhibitory GPCR signaling to explain this abovementioned phenomenon.

\section{ROLES OF CaMKII IN COCAINE REWARD}

\section{The Biological Features of CaMKII}

CaMKII is a holoenzyme composed of subunits expressed by four genes $(\alpha, \beta, \gamma$ and $\delta$; Rosenberg et al., 2010). This enzyme is abundant in brain cells, especially at the synapse. In the rat forebrain, there are two isoforms of CaMKII $\alpha$ and CaMKII $\beta$. The functions and expression features of CaMKII $\alpha$ and CaMKII $\beta$ are different; CaMKII $\alpha$ is expressed specifically in glutamatergic neurons (Liu and Murray, 2012), and the activity of $\alpha$ CaMKII is vital for memory formation and synaptic plasticity (Yamagata et al., 2009). CaMKII $\beta$ is distributed in inhibitory interneurons and glutamatergic neurons (Lamsa et al., 2007). Activated CaMKII can phosphorylate its own autophosphorylation site (T286 in the isoform). Thus, CaMKII can convey information by diverse forms of $\mathrm{Ca}^{2+}$ transients and serve as a dynamic regulator that converts activitydependent $\mathrm{Ca}^{2+}$ signals into different forms of plasticity and synaptic activity (Hudmon and Schulman, 2002; Colbran and Brown, 2004; Griffith, 2004). Recently, many studies have demonstrated that $\mathrm{Ca}^{2+}$ and $\mathrm{Ca}^{2+}$-regulated second messenger systems are involved in the behavioral response to cocaine in animals, and CaMKII plays an important role in the behavioral response to cocaine (Licata et al., 2004; Miller and Marshall, 2004).

\section{CaMKII and Cocaine Behavioral Sensitization}

Cocaine can block the reuptake of DA and result in the accumulation of DA in the synaptic cleft. The accumulated DA can then promote glutamate release, which activates NMDA receptors and causes $\mathrm{Ca}^{2+}$ influx through NMDA receptors as well as L-type $\mathrm{Ca}^{2+}$ channels by activating $\mathrm{D}_{1}$ receptors and desensitizing $\mathrm{D}_{3}$ receptors (Wakabayashi and Kiyatkin, 2012). The influx of $\mathrm{Ca}^{2+}$ causes the activation of CaMKII, which promotes the phosphorylation of various targets and produces different biological effects, such as promoting the influx of $\mathrm{Ca}^{2+}$ and producing locomotion (Easton et al., 2014). Previous studies have shown that injecting an L-type $\mathrm{Ca}^{2+}$ channel antagonist can inhibit the expression of a sensitized behavioral response to amphetamine or cocaine (Park et al., 2001; Mills et al., 2007). Meanwhile, a great deal of research has shown that the overexpression of $\alpha$ CaMKII promotes behavioral sensitization to cocaine. Furthermore, injection of a CaMKII inhibitor (KN-93) into the VTA blunts the behavior sensitization produced by cocaine; consistent with KN-93 findings, behavioral sensitization to cocaine was attenuated in $\alpha$ CaMKII knockdown mice (Licata et al., 2004; Zhen et al., 2007; Kadivar et al., 2014). Together, these data demonstrate that CaMKII activity induced by the influx of $\mathrm{Ca}^{2+}$ can regulate behavioral sensitization to cocaine.

\section{CaMKII and Cocaine-Associated Memories}

Individuals frequently encounter environmental cues previously associated with drug use that can increase craving and the likelihood of relapse (Fuchs et al., 2009; Kalivas, 2009). The ability of drug-associated memories to induce relapse is perhaps the greatest obstacle to the successful treatment of addictive disorders. Previous work has revealed that a single cocaine exposure can induce neuronal activation and long-term potentiation (LTP) in the VTA (the phosphorylation of CaMKII is very important for the induction of LTP; Ungless et al., 2001). Meanwhile, cocaine administration can increase the phosphorylation of CaMKII, and intra-VTA inhibition of CaMKII before cocaine conditioning blocks the acquisition of cocaine conditioned place preference (Liu et al., 2014; Schöpf et al., 2015). Together, those results suggest that CaMKII plays an important role in the formation of cocaine-associated memories. Furthermore, Rich et al. (2016) found that intra-basolateral amygdala inhibition of CaMKII promoted the extinction of cocaine-associated memory and led to a reduction in subsequent cue-induced reinstatement, which provides a novel target for preventing relapse to cocaine use.

\section{ROLES OF INHIBITORY G-PROTEIN COUPLED RECEPTOR SIGNALING IN COCAINE REWARD}

\section{The Biological Features of Inhibitory G-Protein Coupled Receptor Signaling}

GPCRs are seven-transmembrane-domain receptors, which transduce ligand-binding events into intracellular responses. Depending on the $\alpha$ subunit type, GPCRs can be Gas, Gai/o, $\mathrm{G} \alpha \mathrm{q} / 11$ or Ga12/13 (Wettschureck and Offermanns, 2005; Oldham and Hamm, 2008). Gai/o can interact with downstream effectors and inhibit excitatory effectors, including most isoforms of adenylyl cyclase (AC) and some types of voltage-gated 


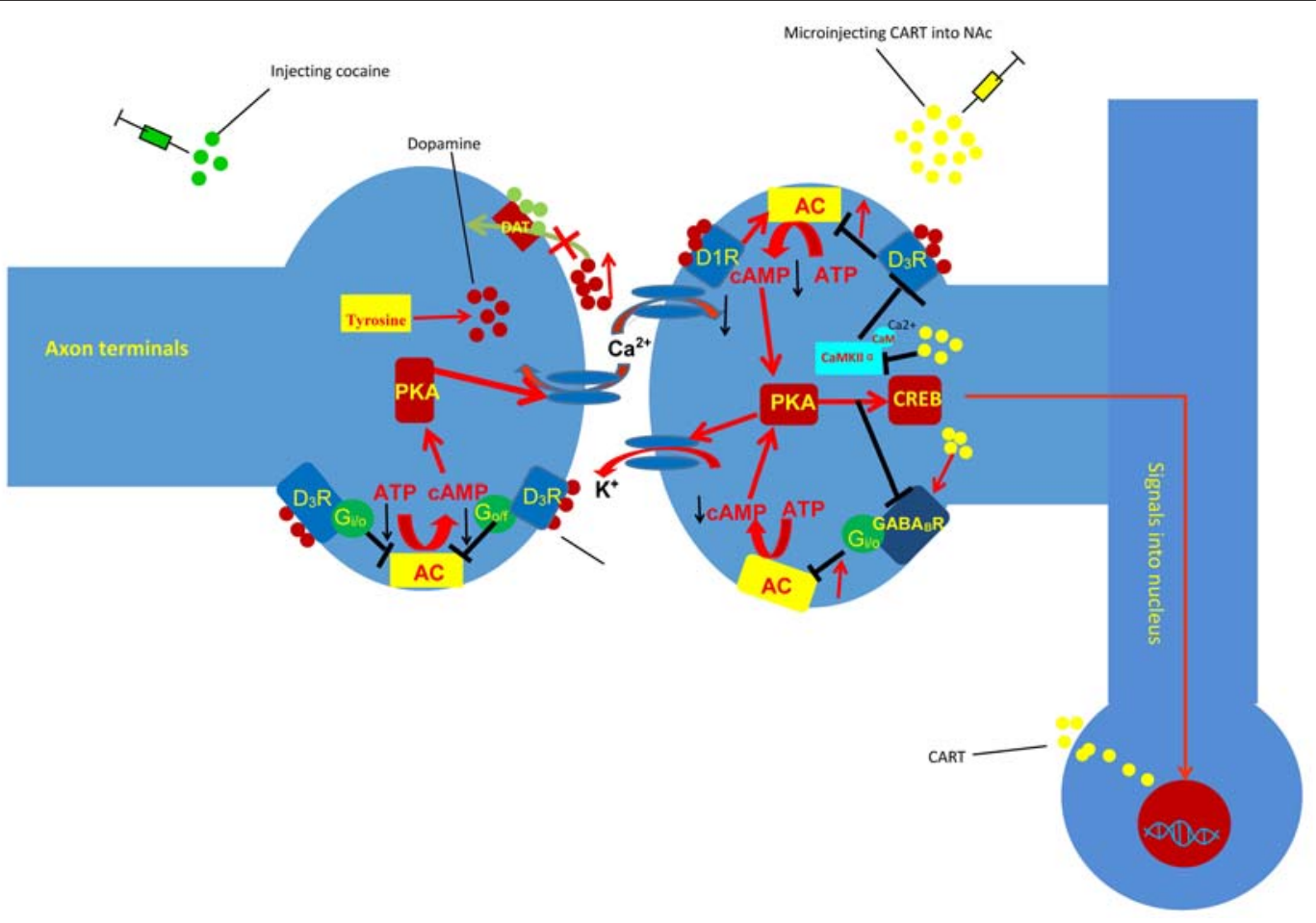

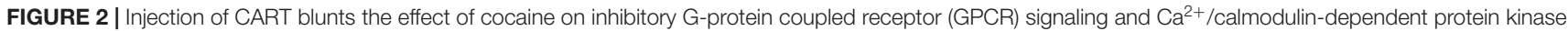
II (CaMKII). Cocaine can block the reuptake of DA and result in the accumulation of DA in the synaptic cleft. The accumulated DA can decrease the sensitivity of the D3 DA autororeceptors located on dopaminergic cells and favor somatodendritic DA release. Conversely, DA activates D1 DA heteroreceptors, desensitizes the D3 DA autoreceptors located on dopaminergic cells, and stimulates AC, resulting in increased intracellular cAMP levels. However, injecting CART into the NAC decreases the phosphorylation of CaMKIll $\alpha$ and $D 3 R$, which inhibits the activity of $A C$ and reduces cocaine-induced $L M A$. $D_{1} R$, dopamine $D 1$ receptor; $D_{3} R$, dopamine D3 receptor; PKA, protein kinase A; ATP, adenosine triphosphate; cAMP, cyclic adenosine monophosphate; AC, adenylyl cyclase; DAT, dopamine transporter; CREB, CAMP-response element binding protein.

$\mathrm{Ca}^{2+}$ channels. Metabotropic $\gamma$-aminobutyric acid receptors $\left(\mathrm{GABA}_{\mathrm{B}} \mathrm{Rs}\right)$ and $\mathrm{D}_{3}$ receptors couple to and activate the Gi/o subclass of $\mathrm{G} \alpha$ subunits and produce inhibitory signaling (Filip et al., 2007). Currently, increasing evidence has indicated that inhibitory GPCR signaling mediated by the Gi/o class of GPCRs for the neurotransmitters GABA $\left(G_{A B A} R\right)$ and $D A\left(D_{3}\right.$ receptors) plays an important role in cocaine reward (Goldstein and Volkow, 2002; Vlachou and Markou, 2010; Figure 2). Many studies have shown that $G_{A B A} R, D_{3} R$ and CART are co-expressed in some brain regions, such as the NAc (Liu et al., 2009; Hubert et al., 2010; Fu et al., 2016). Meanwhile, some research has demonstrated that $\mathrm{GABA}_{B} \mathrm{R}$ and $\mathrm{D} 3 \mathrm{Rs}$ can interact with CART (Hubert et al., 2010; Peng et al., 2014; Fu et al., 2016). Therefore, $\mathrm{GABA}_{\mathrm{B}} \mathrm{Rs}$ and D3Rs, as representative inhibitory GPCR signaling are chosen to illustrate the involvement of inhibitory GPCR signaling in the role of CART in cocaine reward.

\section{GABA $_{B} R$ and Cocaine Reward}

$\mathrm{GABA}_{B}$ Rs are metabotropic receptors that belong to the GPCR superfamily and are responsible for the neuromodulation of GABA (Yamaguchi et al., 2002). The $\mathrm{GABA}_{B} \mathrm{Rs}$ are distributed at pre- and post-synaptic sites. The activation of presynaptic $\mathrm{GABA}_{B} \mathrm{Rs}$ can block calcium channels. The activation of post-synaptic $\mathrm{GABA}_{B} \mathrm{Rs}$ activates potassium channels and increases the flux of potassium from extracellular to intracellular sites. Chronic cocaine administration decreases the functional coupling of $\mathrm{GABA}_{\mathrm{B}}$ receptors in the rat brain (Kushner and Unterwald, 2001; Jayaram and Steketee, 2004). Meanwhile, the $\mathrm{GABA}_{\mathrm{B}} \mathrm{R}$ agonist baclofen attenuates cocaine-induced hyperlocomotion, and intra-VTA application of baclofen blunts cocaine self-administration (Brebner et al., 2000). Furthermore, clinical research has shown that baclofen can attenuate cue-associated cocaine craving and reduce cocaine use in a double-blind placebo-controlled trial (Shoptaw et al., 2003).

\section{$D_{3} R$ and Cocaine Reward}

$\mathrm{D}_{3}$ Rs are GPCRs and belong to the class of $\mathrm{D}_{2}$-like receptors, which can inhibit AC and negatively modulate the activity of PKA and its effectors (Rangel-Barajas et al., 2015). In humans, $\mathrm{D}_{3} \mathrm{Rs}$ are expressed in the islands of Calleja, ventral striatum/NAc, dentate gyrus and striate cortex (Heidbreder et al., 2005). Compared with $D_{2}$ receptors, $D_{3}$ Rs have a high affinity for DA. Small changes in their number or function may lead to dramatic effects on synaptic transmission, suggesting that $\mathrm{D}_{3}$ receptors could be critical for modulating dopaminergic function. Many studies found that a $\mathrm{D}_{3} \mathrm{R}$ agonist (BP897) blunted cocaine-seeking behavior during the presentation of 
cocaine-associated cues in rats (Cervo et al., 2003; Gilbert et al., 2005; Cortés et al., 2016). Furthermore, increasing evidence has shown that selective $\mathrm{D}_{3}$ receptor agonists can attenuate cocaine self-administration (Beardsley et al., 2001; Cheung et al., 2013). Altogether, these studies indicate that $\mathrm{D}_{3}$ Rs play a vital role in cocaine addiction and may be a potential target for drug treatments.

\section{THE INTERACTION OF CART WITH CaMKII AND $D_{3} R$ AFTER REPEATED COCAINE ADMINISTRATION}

Repeated cocaine administration decreases the sensitivity of the $\mathrm{D}_{3} \quad \mathrm{DA}$ autororeceptors located on dopaminergic cells and reduces G-protein-mediated $\mathrm{K}^{+}$efflux, which favors somatodendritic DA release (Licata and Pierce, 2003). Conversely, DA activates $\mathrm{D}_{1}$ DA heteroreceptors, desensitizes the $\mathrm{D}_{3} \mathrm{DA}$ autoreceptors located on dopaminergic cells, and stimulates AC, resulting in increased intracellular cAMP levels (Licata and Pierce, 2003). The increased intracellular cAMP levels can then activate PKA and ultimately upregulate the expression of CART via the cAMP/PKA/CREB signaling pathway (Lakatos et al., 2002). Meanwhile, the $\mathrm{Ca}^{2+}$ influx induced by cocaine can activate CaMKII. Furthermore, the autophosphorylation of CaMKII $\alpha$ (T286) by $\mathrm{Ca}^{2+} / \mathrm{CaM}$ could enhance the binding of CaMKII $\alpha$ to D3Rs, which further stimulates the phosphorylation of D3Rs and transiently inhibits the efficacy of those receptors (Liu et al., 2009). Hence, the influx of $\mathrm{Ca}^{2+}$ induced by cocaine can stimulate CaMKII, which inhibits the activation of $\mathrm{D}_{3} \mathrm{R}$ (Avalos-Fuentes et al., 2015). Furthermore, previous studies have shown that injection of CART into the NAc can decrease the phosphorylation of CaMKII $\alpha$ on threonine (T) 286 and $\mathrm{D}_{3} \mathrm{R}$ (Peng et al., 2014; Fu et al., 2016), which demonstrates that CART can inhibit the activation of CaMKII and further favor the activation of $\mathrm{D}_{3} \mathrm{R}$ (Figure 2).

\section{THE PUTATIVE MECHANISM BY WHICH CART ATTENUATES THE BEHAVIORAL EFFECT OF DOPAMINE}

The influx of DA in the NAc activates the $\mathrm{D}_{1} \mathrm{DA}$ heteroreceptors and desensitizes the $\mathrm{D}_{3}$ DA autoreceptors, which activate downstream targets, such as CREB expression and $\mathrm{Ca}^{2+}$ signaling, and produce LMA. Previous studies have shown that CART attenuates the behavioral effect of cocaine by inhibiting the behavioral effect of DA. However, the mechanisms through which CART inhibits the behavioral effect of DA are not clear. Some research has shown that injecting CART into the NAc decreases the phosphorylation of CaMKII $\alpha$ on threonine (T) 286 and $\mathrm{D}_{3} \mathrm{R}$ and reduces cocaine-induced LMA (Peng et al., 2014; Fu et al., 2016). Meanwhile, research has demonstrated that injection of the CaMKII $\alpha$ inhibitor KN-93 into the NAc attenuates cocaine-enhanced locomotion (Kadivar et al., 2014). Together, those results suggest that CART inhibits $\mathrm{Ca}^{2+}$ signaling and attenuates the behavioral effect of DA by reducing the phosphorylation of CaMKII on threonine (T) 286. Specifically, activated CaMKII $\alpha$ can stimulate the phosphorylation of $\mathrm{D}_{3} \mathrm{Rs}$ and transiently inhibit $\mathrm{D}_{3} \mathrm{R}$ efficacy (Liu et al., 2009). Meanwhile, $\mathrm{D}_{3} \mathrm{Rs}$ could couple with Gi/o proteins and inhibit the cAMP/PKA cascade (Avalos-Fuentes et al., 2015). Considered together, the evidence suggests that CART can inhibit the activation of CaMKII $\alpha$ and further promote the activation of $\mathrm{D}_{3}$ Rs, which reduce the sensitization response to DA and attenuate the behavioral effect of the neurotransmitter (Figure 2).

\section{FUTURE STUDIES}

Since CART was first found to be upregulated by cocaine administration, increasing attention has been paid to the role of CART in cocaine reward (Zhang et al., 2012). Subsequently, other studies have shown that injecting CART into the NAc can attenuate cocaine-induced LMA (Jaworski et al., 2003). By way of explaining this phenomenon further, injecting DA into the NAc results in an increase in LMA, and injecting both DA and CART into the NAc reduces the effect of DA (Kuhar et al., 2005). These findings suggest that CART opposes the actions of cocaine by influencing DA in the NAc. Our previous research has shown that injecting CART into the NAc reduces cocaine-induced LMA by decreasing the phosphorylation of $\mathrm{D}_{3} \mathrm{R}$ and the expression of pCaMKII $\alpha$ (Fu et al., 2016). This result further demonstrates that cocaineinduced LMA also involves CaMKII and $\mathrm{D}_{3} \mathrm{R}$. Furthermore, increasing studies show that $G_{A B A} R$ may also involve in the mechanistic action of CART in cocaine reward. Previous studies have shown that CART peptides are present in a subset of GABAergic projection neurons that express dynorphin, which inhibits the effect of DA by activating the $\kappa$-receptor in the NAc (Dallvechia-Adams et al., 2002; Hubert and Kuhar, 2006). Moreover, CART-containing axons and nerve terminals activate dopaminergic neurons, with some CART peptidepositive terminals forming inhibitory synapses onto GABAergic interneurons in the VTA and substantia nigra (SN; DallvechiaAdams et al., 2001, 2002). Coincidentally, a previous report (Hubert et al., 2010) has shown that CART-containing terminals that originate in the NAc form symmetric synapses onto inhibitory GABAergic synapses and inhibit cocaine-induced locomotion in the ventral pallidum. These studies suggest that there are functional associations between CART and the GABAergic system (Bäckberg et al., 2003). Meanwhile, some studies have shown that $G_{A B A} R$ and CART are highly expressed in NAc (Filip and Frankowska, 2008; Hubert et al., 2010; Fu et al., 2016). Furthermore, injecting CART into the NAc increases $G_{A B A} R$ expression (data not shown). In addition, baclofen $\left(\mathrm{GABA}_{B}\right.$ receptor agonist) antagonizes cocaineinduced DA release in the NAc and blocks cocaine-induced hyperlocomotion (Filip et al., 2015). Considered together, the evidence suggests that CART may attenuate cocaineinduced locomotion by influencing the expression of $G_{A B A} R$. However, further investigations are needed to determine the mechanism by which CART exerts its effect on cocaine-induced locomotion. 
Compulsive drug-taking behavior and high rates of relapse are the two main characteristics of drug addiction. Relapse is a difficult problem to solve in drug addiction treatment and occurs when the drug-seeking habit is reactivated by drug-related cues. Initially, the addict may retrieve from memory strongly compelling drug-related experiences, which then lead to further drug-seeking and drug-taking behavior. Currently, research on the effect of CART on cocaine reward mainly focuses on LMA. There are only a few studies on the effect of CART on relapse. James et al. (2010) found that injecting CART into the PVT attenuates cocaine-seeking behavior in rats. However, the mechanism underlying the inhibitory effect of CART on cocaine-seeking behavior remains unclear. Meanwhile, decreased cocaine-seeking behavior induced by CART may involve $\mathrm{D}_{3} \mathrm{R}$ and $G A B A_{B} R$. $D_{3} R$ agonists and $G A B A_{B} R$ agonists can inhibit cocaine-seeking behavior (Beardsley et al., 2001; Cheung et al., 2013; Blacktop et al., 2016). Furthermore, injecting CART into the NAc decreases the phosphorylation of $\mathrm{D}_{3} \mathrm{R}$ (Fu et al., 2016) and increases $G_{A B A} R$ expression (data not shown).

\section{REFERENCES}

Albertson, D. N., Pruetz, B., Schmidt, C. J., Kuhn, D. M., Kapatos, G., and Bannon, M. J. (2004). Gene expression profile of the nucleus accumbens of human cocaine abusers:evidence for dysregulation of myelin. J. Neurochem. 88, 1211-1219. doi: 10.1046/j.1471-4159.2003.0 2247.x

Asakawa, A., Inui, A., Yuzuriha, H., Nagata, T., Kaga, T., Ueno, N., et al. (2001). Cocaine-amphetamine-regulated transcript influences energy metabolism, anxiety and gastric emptying in mice. Horm. Metab. Res. 33, 554-558. doi: 10.1055/s-2001-17205

Avalos-Fuentes, A., Albarrán-Bravo, S., Loya-Lopéz, S., Cortés, H., RecillasMorales, S., Magaña, J. J., et al. (2015). Dopaminergic denervation switches dopamine $\mathrm{d} 3$ receptor signaling and disrupts its $\mathrm{Ca}^{2+}$ dependent modulation by camkii and calmodulin in striatonigral projections of the rat. Neurobiol. Dis. 74, 336-346. doi: 10.1016/j.nbd.2014. 12.008

Bäckberg, M., Collin, M., Ovesjö, M. L., and Meister, B. (2003). Chemical coding of $\mathrm{GABA}_{\mathrm{B}}$ receptor-immunoreactive neurones in hypothalamic regions regulating body weight. J. Neuroendocrinol. 15, 1-14. doi: 10.1046/j.1365-2826. 2003.00843.x

Bannon, M., Kapatos, G., and Albertson, D. (2005). Gene expression profiling in the brains of human cocaine abusers. Addict. Biol. 10, 119-126. doi: 10.1080/13556210412331308921

Beardsley, P. M., Sokoloff, P., Balster, R. L., and Schwartz, J.-C. (2001). The D3R partial agonist, BP 897, attenuates the discriminative stimulus effects of cocaine and D-amphetamine and is not self-administered. Behav. Pharmacol. 12, 1-11. doi: 10.1097/00008877-200102000-00001

Blacktop, J. M., Vranjkovic, O., Mayer, M., Van Hoof, M., Baker, D. A., and Mantsch, J. R. (2016). Antagonism of GABA-B but not GABA-A receptors in the VTA prevents stress- and intra-VTA CRF-induced reinstatement of extinguished cocaine seeking in rats. Neuropharmacology 102, 197-206. doi: 10.1016/j.neuropharm.2015.11.013

Brebner, K., Phelan, R., and Roberts, D. C. (2000). Intra-VTA baclofen attenuates cocaine self-administration on a progressive ratio schedule of reinforcement. Pharmacol. Biochem. Behav. 66, 857-862. doi: 10.1016/s0091-3057(00)0 0286-0

Cervo, L., Carnovali, F., Stark, J. A., and Mennini, T. (2003). Cocaine-seeking behavior in response to drug-associated stimuli in rats: involvement of $\mathrm{D}_{3}$ and $\mathrm{D}_{2}$ dopamine receptors. Neuropsychopharmacology 28, 1150-1159. doi: 10.1038/sj.npp.1300169

Cheung, T. H., Loriaux, A. L., Weber, S. M., Chandler, K. N., Lenz, J. D., Schaan, R. F., et al. (2013). Reduction of cocaine self-administration and
The totality of the evidence suggests that CART not only reduces the rewarding effects of cocaine by inhibiting cocaine self-administration patterns but also prevents relapse to cocaine use; therefore, it represents an important potential target for drug treatments.

\section{AUTHOR CONTRIBUTIONS}

$\mathrm{CY}$ and $\mathrm{XZ}$ wrote the manuscript. $\mathrm{ZH}$ provided the idea for this work and designed the structure of the manuscript. The other authors revised the manuscript.

\section{FUNDING}

This work was supported by grants from the National Foundation of China (grant no. 81201035, ZH), the Natural Science Foundation of Jiangxi Province (grant no. 20161BBG70065, ZH) and the Health and Family Planning Commission of Jiangxi Province (grant no. 2015A041, ZH).

D3 receptor-mediated behavior by two novel dopamine D3 receptor-selective partial agonists, OS-3-106 and WW-III-55. J. Pharmacol. Exp. Ther. 347, 410-423. doi: 10.1124/jpet.112.202911

Cho, B. R., Yoon, H. S., Kim, W. Y., Vezina, P., and Kim, J. H. (2017). Cocaine inhibits leptin-induced increase of the cocaine- and amphetamine-regulated transcript peptide in the nucleus accumbens in rats. Neuroreport 28, 701-704. doi: 10.1097/WNR.0000000000000822

Colbran, R. J., and Brown, A. M. (2004). Calcium/calmodulin-dependent protein kinase ii and synaptic plasticity. Curr. Opin. Neurobiol. 14, 318-327. doi: 10.1016/s0959-4388(04)00075-3

Cortés, A., Moreno, E., Rodríguez-Ruiz, M., Canela, E. I., and Casadó, V. (2016). Targeting the dopamine $\mathrm{D}_{3}$ receptor: an overview of drug design strategies. Expert Opin. Drug Discov. 11, 641-664. doi: 10.1080/17460441.2016. 1185413

Dallvechia-Adams, S., Kuhar, M. J., and Smith, Y. (2002). Cocaineand amphetamine-regulated transcript peptide projections in the ventral midbrain: colocalization with $\gamma$-aminobutyric acid, melaninconcentrating hormone, dynorphin, and synaptic interactions with dopamine neurons. J. Comp. Neurol. 448, 360-372. doi: 10.1002/cne. 10268

Dallvechia-Adams, S., Smith, Y., and Kuhar, M. J. (2001). Cart peptideimmunoreactive projection from the nucleus accumbens targets substantia nigra pars reticulata neurons in the rat. J. Comp. Neurol. 434, 29-39. doi: $10.1002 /$ cne.1162

Douglass, J., McKinzie, A. A., and Couceyro, P. (1995). PCR differential display identifies a rat brain mRNA that is transcriptionally regulated by cocaine and amphetamine. J. Neurosci. 15, 2471-2481.

Easton, A. C., Lourdusamy, A., Havranek, M., Mizuno, K., Solati, J., Golub, Y., et al. (2014). $\alpha$ CaMKII controls the establishment of cocaine's reinforcing effects in mice and humans. Transl. Psychiatry 4:e457. doi: 10.1038/tp. 2014.97

Fagergren, P., and Hurd, Y. L. (1999). Mesolimbic gender differences in peptide CART mRNA expression: effects of cocaine. Neuroreport 10, 3449-3452. doi: 10.1097/00001756-199911080-00034

Fagergren, P., and Hurd, Y. (2007). CART mRNA expression in rat monkey and human brain: relevance to cocaine abuse. Physiol. Behav. 92, 218-225. doi: 10.1016/j.physbeh.2007.05.027

Filip, M., and Frankowska, M. (2008). GABA B receptors in drug addiction. Pharmacol. Rep. 60, 755-770.

Filip, M., Frankowska, M., and Przegaliński, E. (2007). Effects of GABA $\mathrm{B}$ receptor antagonist, agonists and allosteric positive modulator on the cocaine-induced self-administration and drug discrimination. Eur. J. Pharmacol. 574, 148-157. doi: 10.1016/j.ejphar.2007.07.048 
Filip, M., Frankowska, M., Sadakierska-Chudy, A., Suder, A., Szumiec, L., Mierzejewski, P., et al. (2015). GABA B receptors as a therapeutic strategy in substance use disorders: focus on positive allosteric modulators. Neuropharmacology 88, 36-47. doi: 10.1016/j.neuropharm.2014.06.016

Fu, Q., Zhou, X., Dong, Y., Huang, Y., Yang, J., Oh, K. W., et al. (2016). Decreased caffeine-induced locomotor activity via microinjection of cart peptide into the nucleus accumbens is linked to inhibition of the pcamkiia-d3r interaction. PLoS One 11:e0159104. doi: 10.1371/journal.pone.0159104

Fuchs, R. A., Bell, G. H., Ramirez, D. R., Eaddy, J. L., and Su, Z. I. (2009). Basolateral amygdala involvement in memory reconsolidation processes that facilitate drug context-induced cocaine seeking. Eur. J. Neurosci. 30, 889-900. doi: 10.1111/j.1460-9568.2009.06888.x

Gilbert, J. G., Newman, A. H., Gardner, E. L., Ashby, C. R. Jr., Heidbreder, C. A., Pak, A. C., et al. (2005). Acute administration of SB-277011A, NGB 2904, or BP 897 inhibits cocaine cue-induced reinstatement of drug-seeking behavior in rats: role of dopamine $\mathrm{D}_{3}$ receptors. Synapse 57, 17-28. doi: 10.1002/syn. 20152

Goldstein, R. Z., and Volkow, N. D. (2002). Drug addiction and its underlying neurobiological basis: neuroimaging evidence for the involvement of the frontal cortex. Am. J. Psychiatry 159, 1642-1652. doi: 10.1176/appi.ajp.159. 101642

Griffith, L. C. (2004). Regulation of calcium/calmodulin-dependent protein kinase ii activation by intramolecular and intermolecular interactions. J. Neurosci. 24, 8394-8398. doi: 10.1523/JNEUROSCI.3604-04.2004

Heidbreder, C. A., Gardner, E. L., Xi, Z.-X., Thanos, P. K., Mugnaini, M., Hagan, J. J., et al. (2005). The role of central dopamine $\mathrm{D}_{3}$ receptors in drug addiction: a review of pharmacological evidence. Brain Res. Rev. 49, 77-105. doi: 10.1016/j.brainresrev.2004.12.033

Hou, H., Wang, C., Jia, S., Hu, S., and Tian, M. (2014). Brain dopaminergic system changes in drug addiction: a review of positron emission tomography findings. Neurosci. Bull. 30, 765-776. doi: 10.1007/s12264-0141469-5

Hubert, G. W., Jones, D. C., Moffett, M. C., Rogge, G., and Kuhar, M. J. (2008). Cart peptides as modulators of dopamine and psychostimulants and interactions with the mesolimbic dopaminergic system. Biochem. Pharmacol. 75, 57-62. doi: 10.1016/j.bcp.2007.07.028

Hubert, G. W., and Kuhar, M. J. (2006). Colocalization of cart peptide with prodynorphin and dopamine $\mathrm{d} 1$ receptors in the rat nucleus accumbens. Neuropeptides 40, 409-415. doi: 10.1016/j.npep.2006. 09.001

Hubert, G. W., Manvich, D. F., and Kuhar, M. J. (2010). Cocaine and amphetamine-regulated transcript-containing neurons in the nucleus accumbens project to the ventral pallidum in the rat and may inhibit cocaineinduced locomotion. Neuroscience 165, 179-187. doi: 10.1016/j.neuroscience. 2009.10013

Hudmon, A., and Schulman, H. (2002). Neuronal $\mathrm{Ca}^{2+} /$ calmodulin-dependent protein kinase II: the role of structure and autoregulation in cellular function. Annu. Rev. Biochem. 71, 473-510. doi: 10.1146/annurev.biochem.71.110601. 135410

Hunter, R. G., Vicentic, A., Rogge, G., and Kuhar, M. J. (2005). The effects of cocaine on cart expression in the rat nucleus accumbens: a possible role for corticosterone. Eur. J. Pharmacol. 517, 45-50. doi: 10.1016/j.ejphar.2005. 05.025

James, M. H., Charnley, J. L., Jones, E., Levi, E. M., Yeoh, J. W., Flynn, J. R., et al. (2010). Cocaine- and amphetamine-regulated transcript (CART) signaling within the paraventricular thalamus modulates cocaineseeking behaviour. PLoS One 5:e12980. doi: 10.1371/journal.pone. 0012980

Jaworski, J. N., Hansen, S. T., Kuhar, M. J., and Mark, G. P. (2008). Injection of cart (cocaine- and amphetamine-regulated transcript) peptide into the nucleus accumbens reduces cocaine self-administration in rats. Behav. Brain Res. 191, 266-271. doi: 10.1016/j.bbr.2008.03.039

Jaworski, J. N., Kimmel, H. L., Mitrano, D. A., Tallarida, R. J., and Kuhar, M. J. (2007). Intra-vta cart 55-102 reduces the locomotor effect of systemic cocaine in rats: an isobolographic analysis. Neuropeptides 41, 65-72. doi: 10.1016/j. npep.2006.12.003

Jaworski, J. N., Kozel, M. A., Philpot, K. B., and Kuhar, M. J. (2003). Intraaccumbal injection of CART (cocaine-amphetamine regulated transcript) peptide reduces cocaine-induced locomotor activity. J. Pharmacol. Exp. Ther 307, 1038-1044. doi: 10.1124/jpet.103.052332

Jayaram, P., and Steketee, J. D. (2004). Effects of repeated cocaine on medial prefrontal cortical $\mathrm{GABA}_{\mathrm{B}}$ receptor modulation of neurotransmission in the mesocorticolimbic dopamine system. J. Neurochem. 90, 839-847. doi: 10.1111/j.1471-4159.2004.02525.x

Kadivar, M., Farahmandfar, M., Ranjbar, F. E., and Zarrindast, M. R. (2014). Increased calcium/calmodulin-dependent protein kinase ii activity by morphine-sensitization in rat hippocampus. Behav. Brain Res. 267, 74-82. doi: 10.1016/j.bbr.2014.03.035

Kalivas, P. W. (2009). The glutamate homeostasis hypothesis of addiction. Nat. Rev. Neurosci. 10, 561-572. doi: 10.1038/nrn2515

Kimmel, H. L., Gong, W., Vechia, S. D., Hunter, R. G., and Kuhar, M. J. (2000). Intra-ventral tegmental area injection of rat cocaine and amphetamineregulated transcript peptide 55-102 induces locomotor activity and promotes conditioned place preference. J. Pharmacol. Exp. Ther. 294, 784-792.

Kong, W., Stanley, S., Gardiner, J., Abbott, C., Murphy, K., Seth, A., et al. (2003). A role for arcuate cocaine and amphetamine-regulated transcript in hyperphagia, thermogenesis, and cold adaptation. FASEB J. 17, 1688-1690. doi: 10.1096/fj. 02-0805fje

Koylu, E. O., Balkan, B., Kuhar, M. J., and Pogun, S. (2006). Cocaine and amphetamine regulated transcript (CART) and the stress response. Peptides 27, 1956-1969. doi: 10.1016/j.peptides.2006.03.032

Kuhar, M. J., Jaworski, J. N., Hubert, G. W., Philpot, K. B., and Dominguez, G. (2005). Cocaine- and amphetamine-regulated transcript peptides play a role in drug abuse and are potential therapeutic targets. AAPS J. 7, E259-E265. doi: 10.1208/aapsj070125

Kuriyama, G., Takekoshi, S., Tojo, K., Nakai, Y., Kuhar, M. J., and Osamura, R. Y. (2004). Cocaine- and amphetamine-regulated transcript peptide in the rat anterior pituitary gland is localized in gonadotrophs and suppresses prolactin secretion. Endocrinology 145, 2542-2550. doi: 10.1210/en.200 3-0845

Kushner, S. A., and Unterwald, E. M. (2001). Chronic cocaine administration decreases the functional coupling of $\mathrm{GABA}_{\mathrm{B}}$, receptors in the rat ventral tegmental area as measured by baclofen-stimulated ${ }^{35} \mathrm{~S}-\mathrm{GTP} \gamma \mathrm{S}$ binding. Life Sci. 69, 1093-1102. doi: 10.1016/s0024-3205(01)01203-6

Lakatos, A., Dominguez, G., and Kuhar, M. J. (2002). CART promoter CRE site binds phosphorylated CREB. Mol. Brain Res. 104, 81-85. doi: 10.1016/s0169328x(02)00321-2

Lamsa, K., Irvine, E. E., Giese, K. P., and Kullmann, D. M. (2007). NMDA receptordependent long-term potentiation in mouse hippocampal interneurons shows a unique dependence on $\mathrm{Ca}^{2+} /$ calmodulin-dependent kinases. J. Physiol. 584, 885-894. doi: 10.1113/jphysiol.2007.137380

Larsen, P. J., Seier, V., Fink-Jensen, A., Holst, J. J., Warberg, J., and Vrang, N. (2003). Cocaine- and amphetamine-regulated transcript is present in hypothalamic neuroendocrine neurones and is released to the hypothalamicpituitary portal circuit. J. Neuroendocrinol. 15, 219-226. doi: 10.1046/j.13652826.2003.00960.x

Licata, S. C., and Pierce, R. C. (2003). The roles of calcium/calmodulindependent and ras/mitogen-activated protein kinases in the development of psychostimulant-induced behavioral sensitization. J. Neurochem. 85, 14-22. doi: 10.1046/j.1471-4159.2003.01662.x

Licata, S. C., Schmidt, H. D., and Pierce, R. C. (2004). Suppressing calcium/calmodulin-dependent protein kinase II activity in the ventral tegmental area enhances the acute behavioural response to cocaine but attenuates the initiation of cocaine-induced behavioural sensitization in rats. Eur. J. Neurosci. 19, 405-414. doi: 10.1111/j.0953-816x.2003.03110x

Liu, X., Liu, Y., Zhong, P., Wilkinson, B., Qi, J., Olsen, C. M., et al. (2014). Camkii activity in the ventral tegmental area gates cocaine-induced synaptic plasticity in the nucleus accumbens. Neuropsychopharmacology 39, 989-999. doi: $10.1038 / \mathrm{npp} .2013 .299$

Liu, X.-Y., Mao, L.-M., Zhang, G.-C., Papasian, C. J., Fibuch, E. E., Lan, H. X., et al. (2009). Activity-dependent modulation of limbic dopamine D3 receptors by CaMKII. Neuron 61, 425-438. doi: 10.1016/j.neuron.2008. 12.015

Liu, X. B., and Murray, K. D. (2012). Neuronal excitability and calcium/calmodulin-dependent protein kinase type II: location, location, location. Epilepsia 53, 45-52. doi: 10.1111/j.1528-1167.2012.03474.x 
Lohoff, F. W., Bloch, P. J., Weller, A. E., Nall, A. H., Doyle, G. A., Buono, R. J., et al. (2008). Genetic variants in the cocaine- and amphetamine-regulated transcript gene (CARTPT) and cocaine dependence. Neurosci. Lett. 440, 280-283. doi: 10.1016/j.neulet.2008.05.073

Miller, C. A., and Marshall, J. F. (2004). Altered prelimbic cortex output during cue-elicited drug seeking. J. Neurosci. 24, 6889-6897. doi: 10.1523/JNEUROSCI.1685-04.2004

Mills, K., Ansah, T. A., Ali, S. F., Mukherjee, S., and Shockley, D. C. (2007). Augmented behavioral response and enhanced synaptosomal calcium transport induced by repeated cocaine administration are decreased by calcium channel blockers. Life Sci. 81, 600-608. doi: 10.1016/j.lfs.2007. 06.028

Nader, M. A., Daunais, J. B., Moore, T., Nader, S. H., Moore, R. J., Smith, H. R., et al. (2002). Effects of cocaine self-administration on striatal dopamine systems in rhesus monkeys: initial and chronic exposure. Neuropsychopharmacology 27, 35-46. doi: 10.1016/S0893-133X(01)00427-4

Oldham, W. M., and Hamm, H. E. (2008). Heterotrimeric G protein activation by G-protein-coupled receptors. Nat. Rev. Mol. Cell Biol. 9, 60-71. doi: 10.1038/nrm2299

Park, K., Vora, U., Darling, S. F., Kolta, M. G., and Soliman, K. F. A. (2001). The role of inducible nitric oxide synthase in cocaine-induced locomotor sensitization. Physiol. Behav. 74, 441-447. doi: 10.1016/s0031-9384(01) 00588-1

Peng, Q., Sun, X., Liu, Z., Yang, J., Oh, K. W., and Hu, Z. (2014). Microinjection of cart (cocaine- and amphetamine-regulated transcript) peptide into the nucleus accumbens inhibits the cocaine-induced upregulation of dopamine receptors and locomotor sensitization. Neurochem. Int. 75, 105-111. doi: 10.1016/j. neuint.2014.06.005

Perry Barrett, M. D., Davidson, J., and Morgan, P. (2002). CART gene promoter transcription is regulated by a cyclic adenosine monophosphate response element. Obes. Res. 10, 1291-1298. doi: 10.1038/oby.2002.175

Pomara, C., Cassano, T., D'Errico, S., Bello, S., Romano, A. D., Riezzo, I., et al. (2012). Data available on the extent of cocaine use and dependence: biochemistry, pharmacologic effects and global burden of disease of cocaine abusers. Curr. Med. Chem. 19, 5647-5657. doi: 10.2174/0929867128039 88811

Rangel-Barajas, C., Coronel, I., and Florán, B. (2015). Dopamine receptors and neurodegeneration. Aging Dis. 6, 349-368. doi: 10.14336/AD.2015.0330

Rich, M. T., Abbott, T. B., Chung, L., Gulcicek, E. E., Stone, K. L., Colangelo, C. M., et al. (2016). Phosphoproteomic analysis reveals a novel mechanism of camkii $\alpha$ regulation inversely induced by cocaine memory extinction versus reconsolidation. J. Neurosci. 36, 7613-7627. doi: 10.1523/JNEUROSCI.110816.2016

Robson, A. J., Rousseau, K., Loudon, A. S. I., and Ebling, F. J. P. (2002). Cocaine and amphetamine-regulated transcript mrna regulation in the hypothalamus in lean and obese rodents. J. Neuroendocrinol. 14, 697-709. doi: 10.1046/j.13652826.2002.00830.x

Rodrigues, B. C., Cavalcante, J. C., and Elias, C. F. (2011). Expression of cocaineand amphetamine-regulated transcript in the rat forebrain during postnatal development. Neuroscience 195, 201-214. doi: 10.1016/j.neuroscience.2011. 08.036

Rosenberg, O. S., Deindl, S., Sung, R. J., Nairn, A. C., and Kuriyan, J. (2010). Structure of the autoinhibited kinase domain of camkii and saxs analysis of the holoenzyme. Cell 123, 849-860. doi: 10.1016/j.cell.2005. 10029

Schöpf, I., Easton, A. C., Solati, J., Golub, Y., Kornhuber, J., Giese, K. P., et al. (2015). aCaMKII autophosphorylation mediates neuronal activation in the hippocampal dentate gyrus after alcohol and cocaine in mice. Neurosci. Lett. 591, 65-68. doi: 10.1016/j.neulet.2015.02.031
Shoptaw, S., Yang, X., Rotheram-Fuller, E. J., Hsieh, Y. C., Kintaudi, P. C., Charuvastra, V. C., et al. (2003). Randomized placebo-controlled trial of baclofen for cocaine dependence: preliminary effects for individuals with chronic patterns of cocaine use. J. Clin. Psychiatry 64, 1440-1448. doi: $10.4088 /$ jcp.v64n1207

Spiess, J., Villarreal, J., and Vale, W. (1981). Isolation and sequence analysis of a somatostatin-like polypeptide from ovine hypothalamus. Biochemistry 20, 1982-1988. doi: 10.1021/bi00510a038

Ungless, M. A., Whistler, J. L., Malenka, R. C., and Bonci, A. (2001). Single cocaine exposure in vivo induces long-term potentiation in dopamine neurons. Nature 411, 583-587. doi: 10.1038/35079077

United Nations Office on Drug and Crime (UNODC). (2016). World Drug Report. Available online at: http://www.unodc.org/wdr2016/

Vlachou, S., and Markou, A. (2010). GABA B receptors in reward processes. Adv. Pharmacol. 58, 315-371. doi: 10.1016/s1054-3589(10)58013-x

Volkoff, H., and Peter, R. E. (2001). Characterization of two forms of cocaine- and amphetamine-regulated transcript (CART) peptide precursors in goldfish: molecular cloning and distribution, modulation of expression by nutritional status, and interactions with leptin. Endocrinology 142, 5076-5088. doi: 10.1210/endo.142.12.8519

Vrang, N., Larsen, P. J., and Kristensen, P. (2002). Cocaine-amphetamine regulated transcript (CART) expression is not regulated by amphetamine. Neuroreport 13, 1215-1218. doi: 10.1097/00001756-20020702000029

Wakabayashi, K. T., and Kiyatkin, E. A. (2012). Rapid changes in extracellular glutamate induced by natural arousing stimuli and intravenous cocaine in the nucleus accumbens shell and core. J. Neurophysiol. 108, 285-299. doi: 10.1152 /jn.01167.2011

Wettschureck, N., and Offermanns, S. (2005). Mammalian G proteins and their cell type specific functions. Physiol. Rev. 85, 1159-1204. doi: 10.1152/physrev. 00003.2005

Yamagata, Y., Kobayashi, S., Umeda, T., Inoue, A., Sakagami, H., Fukaya, M., et al. (2009). Kinase-dead knock-in mouse reveals an essential role of kinase activity of $\mathrm{Ca}^{2+} /$ calmodulin-dependent protein kinase II $\alpha$ in dendritic spine enlargement, long-term potentiation, and learning. J. Neurosci. 29, 7607-7618. doi: 10.1523/JNEUROSCI.070709.2009

Yamaguchi, M., Suzuki, T., Abe, S., Baba, A., Hori, T., and Okado, N. (2002). Repeated cocaine administration increases $\mathrm{GABA}^{\mathrm{B}(1)}$ subunit mrna in rat brain. Synapse 43, 175-180. doi: 10.1002/syn.10037.abs

Zhang, M., Han, L., and Xu, Y. (2012). Roles of cocaine- and amphetamineregulated transcript in the central nervous system. Clin. Exp. Pharmacol. Physiol. 39, 586-592. doi: 10.1111/j.1440-1681.2011.05642.x

Zhen, X., Goswami, S., Abdali, S. A., Frankfurt, M., and Friedman, E. (2007). Estrogen-modulated frontal cortical camkii activity and behavioral supersensitization induced by prolonged cocaine treatment in female rats. Psychopharmacology (Berl) 191, 323-331. doi: 10.1007/s00213-0060648-0

Conflict of Interest Statement: The authors declare that the research was conducted in the absence of any commercial or financial relationships that could be construed as a potential conflict of interest.

Copyright (c) $2017 \mathrm{Yu}$, Zhou, Fu, Peng, Oh and Hu. This is an open-access article distributed under the terms of the Creative Commons Attribution License (CC BY). The use, distribution or reproduction in other forums is permitted, provided the original author(s) or licensor are credited and that the original publication in this journal is cited, in accordance with accepted academic practice. No use, distribution or reproduction is permitted which does not comply with these terms. 